\title{
Eddig és ezután - Folyóiratunk megújításával kapcsolatos idei tapasztalatok, valamint jövőbeni terveink bemutatása
}

\author{
Till now and after this - This year's experiences related to our renewed jour- \\ nal and our plan for the future
}

\section{Honnan indultunk?}

A Nemzeti Egészségfejlesztési Intézet (NEFI) szakmai folyóirata, az Egészségfejlesztés 2016. évben megjelenő, 57. évfolyammal kezdődően megújult. A változás célja volt, hogy a lap mind megjelenésében, mind tartalmában jobban illeszkedjen a megváltozott népegészségügyi kihívásokhoz. Ennek érdekében - a hazai népegészségügy területén az elsők között - csak szakbírálaton átesett (peer-reviewed) eredeti közlemények kerülhetnek közlésre a lapban, ezzel is előmozdítva, hogy szakmai körökben is elismertté és idézetté váljon az Egészségfejlesztés. A megújulás részeként intézetünk folyóirata elektronikusan jelenik meg, és ingyenesen elérhető.

A lap kiadásának célja a NEFI egészségfejlesztés szakterületen betöltött módszertani szerepének erősítése, a szakterületen dolgozók, az érdeklődők megfelelő minőségű szakmai tájékoztatása a területet érintő hazai és nemzetközi tevékenységekről, eredményekről, valamint szakmai fórum biztosítása az eltérő álláspontok, vélemények ütköztetésére.

Az Egészségfejlesztés a jelenleg és a jövőben egészségfejlesztéssel foglalkozó, vagy azzal kapcsolatba kerülő szakemberek számára készül. A széleskörű célközönségből adódóan a megújított folyóiratban egyaránt megjelenhetnek szakbírálók által minőségbiztosított tudományos publikációk, szakmai beszámolók, az egészségfejlesztés területéről származó legfrissebb hírek, fejlesztések, érdekességek, vélemények is.

\section{Hova jutottunk?}

Az Egészségfejlesztés című folyóirat elektronikus formában továbbra is negyedévente jelenik meg. Az elektronikus megjelenés támogatásához, szerkesztőségünk az erre a célra kifejlesztett Open Journal
Systems informatikai rendszert használja, amely garantálja a nemzetközi gyakorlatnak megfelelő anonim szakbírálatok nyomon követhetőségét, a magas színvonalú, átlátható szerkesztőségi munkát. Az új feladathoz a folyóirat szerkesztősége és Tanácsadó Testülete is átalakult.

Mint minden változás, a folyóirat megújítása is számos nehézséggel járt, amelyek közül a legnagyobb kihívást a szerkesztés minőségének javítását célzó új munkafolyamatokra való átállás és az elektronikus megjelenést támogató szoftver alkalmazása jelentette. A rendszer használatát nemcsak a szerkesztőknek, hanem a szerzőknek és szakbírálóknak is meg kellett ismerniük, ehhez honlapon elérhető részletes információt valamint - kérésre - technikai támogatást nyújtottunk. A változás az előfizetőink és olvasóink számára is néha problémát jelentett, azonban reméljük, hogy az év végére az elektronikus és ingyenes elérhetőség előnyei feledtetik ezt.

A folyóirat megújítása - természetesen - intenzív munkát követelt és követel a szerkesztőktől, amelyhez a motivációt, a kitartást a szakmai elkötelezettség, a színvonal emelésére irányuló közös szándék adta és adja. A megújulás elképzelhetetlen lett volna az Intézet sok munkatársának lelkesedése nélkül, hiszen ők szerzőként járultak hozzá a közös sikerhez. Külön köszönet illeti önkéntes munkájukért az eredeti közlemények szakbírálóit: Brys Zoltánt, Formanek-Balku Esztert, Pénzes Melindát, Simon Tamást, Solymosy József Bonifáczot, Terebessy Andrást és Vandlik Erikát.

Folyóiratunk 57. évfolyama a terveknek megfelelően időben, 4 számmal jelent meg, több mint ötven közleménnyel. A megújult folyóirat honlapjának látogatottsági statisztikájából egyértelműen kiderül, hogy az első elektronikus megjelenés óta folyamatosan növekszik az Egészségfejlesztés olvasottsága. 
Bizakodásra adhat okot, hogy novemberig az érdeklődők több mint 13000-szer keresték fel a szaklap honlapját. [1. ábra] Az eddigi legolvasottabb közlemények az első lapszámban meg-jelenő Iskoláskorú gyermekek egészségmagatartása kutatást, valamint az Egészségjelentés2015 tanulmányt bemutató írások voltak; mindkettőt közel 180-szor tekintették meg.

\section{Hova tartunk?}

A szerkesztőség terveiben szerepel a külső szerzők által beküldött közlemények számának növelése, ebben különösképp számítunk a Tanácsadó Testület tagjainak közbenjárására. Az egészségfejlesztés területéhez kapcsolódó egyetemeket és doktori isko- lákat is megkeressük, hogy bátorítsák szakembereiket, kutatóikat az Egészségfejlesztésbe való közlésre, továbbá, hogy folyóiratunk felkerülhessen az oktatási intézmények által javasolt és elfogadott szakmai kiadványok listájára. Ehhez megtettük az első lépéseket: a közeli jövőben cikkeinket a nemzetközi gyakorlatban elterjedt DOI azonosító számmal látjuk el. Hamarosan elindítjuk azt az eljárást is, amelynek eredményeképpen folyóiratunk a legnagyobb nemzetközi adatbázisokban is kereshetővé válik. A szerkesztőség mindent megtesz annak érdekében, hogy a megújult folyóirat további megjelenéséhez szükséges feltételek a minisztériumi háttérintézmények átalakítását követően is rendelkezésre álljanak majd, hogy a lap a jövőben is beteljesíthesse küldetését.

1. ábra: az Egészségfejlesztés folyóirat honlapjának napi átlagos és havonkénti összesitett látogatóinak száma (2016. április-november)

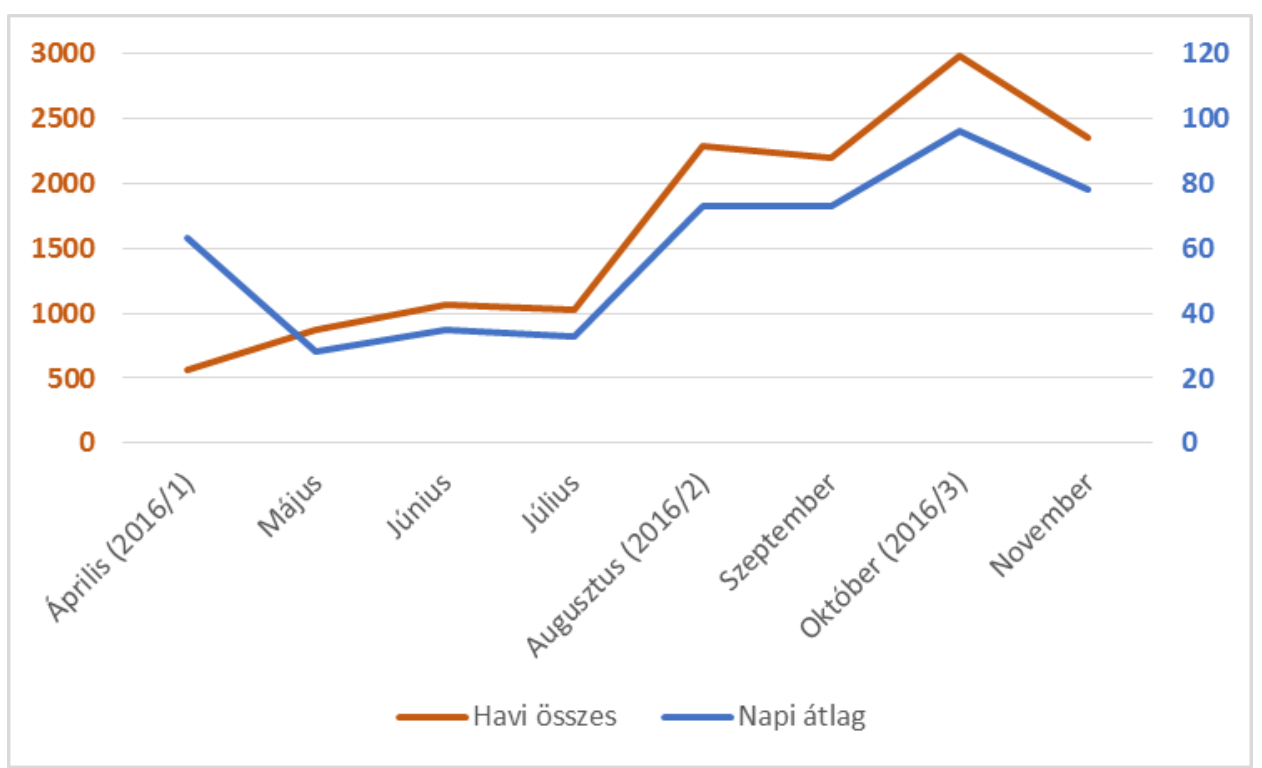

Forrás: saját szerkesztés

Vitrai József felelős szerkesztő 